\title{
Strategiese bemarkingsbestuur by enkele leweransiers aan die landbou in die Republiek van Suid-Afrika
}

\author{
J.J. van Zyl \\ Departement Bedryfsekonomie, PU vir CHO, Potchefstroom
}

\begin{abstract}
Strategic marketing management of some suppliers to the Agricultural sector in the Republic of South Africa The Republic of South Africa is at present in a state of change within the economical, political, social, institutional, physical and international environments. Change in these fields is still in an early phase and rapid changes can be expected in future. From a management point of view, these changes are a fact and must be considered and taken into account in the decision-making process. Modern enterprise in the free-market system functions within the framework of the changing environment and the ability to grow and develop are dependent on the ability of the individual firm to adapt to these changes. The aim of the research was to determine how marketing management of some suppliers of capital equipment to the agricultural sector apply strategic marketing principles and practices, to enable their firms to adapt to constant external changes. Apart from a theoretical background some empirical research was undertaken to determine the composition of the management and marketing strategies. The emphasis is, however, on the formulation of the marketing strategy and the implementation of the marketing strategy.

S. Afr. J. Bus. Mgmt. 1986, 17: $93-100$
\end{abstract}

Die Republiek van Suid-Afrika bevind hom tans in 'n tydperk van strukturele veranderings op die gebied van die ekonomiese, politieke, sosiale, institusionele, maatskaplike, fisieke en internasionale omgewings. Vanuit 'n bestuurs. oogpunt is verandering nie meer 'n seldsaamheid nie, maar 'n werklikheid wat in die besluitnemingsproses in ag geneem moet word. Die moderne onderneming in 'n vryemarkstelsel funksioneer binne die raamwerk van veranderinge wat deur die eksterne omgewing daargestel word. Die vermoë van ' $n$ onderneming in 'n vryemarkstelsel om te groei en te ontwikkel word grootliks bepaal deur die vermoë om by die veranderende eksterne omgewing aan te pas en voortdurend die verbruiker se behoeftes met produkte en/of dienste te bevredig. Die doel van hierdie navorsing was om te bepaal of die leweransiers van kapitaaltoerusting aan die landbou in die Republiek van Suid-Atrika strategiese bemarkingsbestuur toepas. Ten spyte van die verskeidenheid literatuur wat oor die onderwerp, strategiese bemarkingsbestuur bestaan, is dit nie altyd duidelik of strategiese bemarkingsbestuur wel in die praktyk inslag gevind het nie.

S.Afr. Tydskr. Bedryfsl. 1986, 17: $93-100$

\section{J.J. van Zyl}

Departement Bedryfsekonomie, PU vir CHO, Potchefstroom, 2520

Republiek van Suid Afrika

\section{Inleiding}

Die Republiek van Suid-Afrika bevind hom tans in ' $n$ tydperk van strukturele en sikliese veranderings op die gebied van die ekonomiese, politieke, sosiale, institusionele, maatskaplike, fisieke en internasionale omgewings.

Die proses van verandering en aanpassing in Suid-Afrika is in die beginstadium en nog groter veranderings en aanpassings as wat in die verlede plaasgevind het, sal moontlik in die toekoms gemaak moet word. Verandering en aanpassing is vir die Suid-Afrikaanse bedryfsleier nie ' $n$ onbekende of seldsame verskynsel nie, maar dit verg egter nie die besondere gawes van 'n siener of waarsêer om te kan voorspel dat die tempo en die aard van toekomstige veranderings ' $n$ meer veeleisende en gekompliseerde omgewingsraamwerk, waarbinne die bedryfsleier en die onderneming sal moet optree, tot gevolg gaan hê nie. Die moderne onderneming funksioneer binne die raamwerk wat deur die eksterne omgewing daargestel word.

Die ekonomiese bestaansreg en groei van ondernemings in 'n vryemarkstelsel word onder andere bepaal deur die vermoë van dié ondernemings om binne ' $n$ veranderende omgewing die behoeftes van hulle klante voortdurend met produkte en/of dienste te bevredig en die mate waartoe die lang- en korttermyn rentabiliteitsdoelwitte van die onderneming verwesenlik word (Marx \& Bolt, 1983:20).

Die bemarkingsbestuur het ' $n$ belangrike rol om te vervul om die onderneming te help om by die veranderende omstandighede, soos deur die eksterne omgewing bepaal, aan te pas. Die kernvraag is egter: hoe moet die bemarkingsbestuur optree om die onderneming te help om by die veranderende eksterne omgewing aan te pas? Op grond van empiriese navorsing (en die resultate van die navorsing) wat in die Verenigde State van Amerika uitgevoer is, is van die standpunt uitgegaan dat die uitvoering van strategiese bemarkingsbestuur die bemarkingsbestuur in staat sal stel om die onderneming, binne die raamwerk van die veranderende eksterne omgewing, tot doelwitbereiking te lei.

\section{Doel}

Die doel van die navorsing was om deur middel van teoretiese en empiriese ondersoeke vas te stel hoe die bemarkingsbestuur van enkele leweransiers van kapitaaltoerusting aan die landbousektor, strategiese bemarkingsbestuur toepas ten einde hulle ondernemings in staat te stel om by die drasties-veranderende eksterne omgewing aan te pas.

'n Ondersoek is geloods om vas te stel waaruit die bestuurstrategieè van hierdie leweransiers bestaan en om die rol wat die bemarkingstrategie in die bestuurstrategie vervul te bepaal. 
Die klem het egter hoofsaaklik op die formulering van die bemarkingstrategie, die implementering van die bemarkingstrategie en die invloed wat die bemarkingstrategie op die organisasiestruktuur het, geval. In hierdie artikel word slegs aandag geskenk aan die formulering en die implementering van die bemarkingstrategie.

\section{Metode}

Die navorsing is in twee ondersoekfases afgehandel, naamlik 'n literatuurstudie en 'n empiriese studie. Die literatuurstudie het bestaan uit 'n ontleding van die literatuur oor strategiese bestuur en strategiese bemarkingsbestuur. Uit die bestaande literatuur is 'n model saamgestel wat as raamwerk vir die invoering van strategiese bemarkingsbestuur kan dien. Die model is grootliks op vorige navorsing van Marx \& Bolt (1983:20) gebaseer. Wysiging is aan dié model aangebring nadat dit met die modelle van Hofer \& Schendel (1978:49), Steiner \& Miner (1977:18), Luck \& Ferrel (1979:16), Kotler (1980:63), Godivalla (1983:223) en die model van die Instituut vir Toekomsstudies (PU vir $\mathrm{CHO}$ ) vergelyk is.

Figuur 1 is 'n voorstelling van die model wat as teoretiese verwysingsraamwerk ontwikkel is. Indien 'n strategiese bemarkingsbestuursbenadering gevolg word, vervul die mark 'n baie belangrike rol in die bestuurstrategie. Die sterk- en swakpunte van die onderneming se vermoëns word gemeet in terme van die geleenthede en bedreigings wat in die mark bestaan. Die bestuurstrategie word ook met die mededingende voordele wat die onderneming in die mark geniet as uitgangspunt geformuleer. Die bestuurstrategie word saamgestel uit 'n beplanningen operasionele strategie (Marx \& Bolt, 1983:25). Die beplanningstrategie is die resultaat van 'n denkproses waartydens die bemarkingsbestuur besluite moet neem oor die ondernemingsmissie, lang- en korttermynondernemingsdoelwitte, en die geleenthede en bodreigings in die eksterne omgewing, die sterken swakpunte van die interne vermoëns van die onderneming, doelwitgapings en strategieë om die doelwitgapings te vul. Vanuit 'n bemarkingsoogpunt is die strategiese keuse 'n produk. ontwikkeling-en/of 'n markontwikkelingsbesluit. Die besluite wat geneem is om die beplanningstrategie te vorm moet geimplementer word. Die operasionele strategie is die instrument waarmee die beplanningstrategie tot optrede omgeskakel word.

Gedurende die empiriese fase van die navorsing is gepoog om vas te stel of strategiese bemarkingsbestuur in die praktyk toegepas word. Die leweransiers aan die landbousektor in die Republiek van Suid-Afrika is as ondernemings, wat in ' dinamiese en voortdurend-veranderende eksterne omgewing funksioneer, geïdentifiseer. In die landbousektor kom die invloed wat die eksterne omgewing op die onderneming het, baie duidelik na vore. Die droogtetoestande wat die afgelope drie seisoene geheers het asook veranderinge in rentekoerse en wisselkoerse het ' $n$ invloed op die lede van die landbousektor en die leweransiers aan dié sektor. In die navorsing is slegs ondersoek ingestel na die toepassing van strategiese bemarkingsbestuur deur die leweransiers aan die landbousek. tor. Die landbousektor dien dus slegs as 'n parameter om ondernemings wat in 'n dinamiese eksterne omgewing funksioneer, te identifiseer. As gevolg van die verskeidenheid leweransiers van intermediêre insette aan die landbou is besluit om slegs die leweransiers van kapitaalinsette by die navorsing te betrek. Die oordeelsteekproef (Curchill, 1983:345) is gebruik om die leweransiers te identifiseer wat aan die doel van die navorsing sou voldoen. Slegs ondernemings met 200 en meer werknemers in diens is by die ondersoek ingesluit. 'n Groep van 31 leweransiers (kapitaalinsette) het aan die vereiste voldoen. Deur middel van 'n voorlopige posopname en telefoonopname het 20 van die leweransiers hulle bereid verklaar om aan die navorsing deel te neem. Die finale groep leweransiers wat aan die navorsing deelgeneem het, het uit 11 vervaardigers van motorvoertuie, vier vervaardigers van trekkers en vyf vervaardigers van landboumasjinerie en -implemente, bestaan.

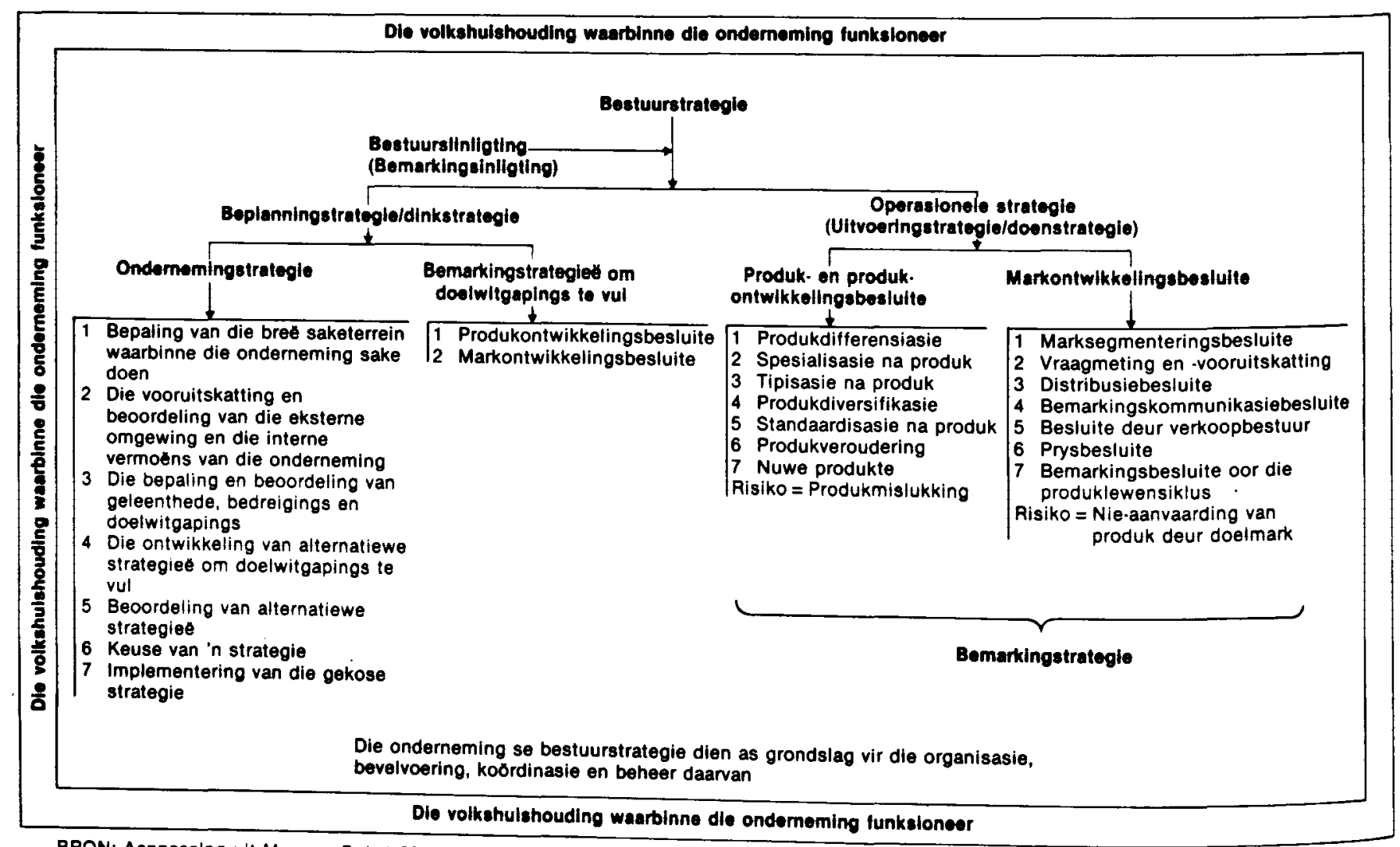

BRON: Aanpassing ult Marx en Bolt (1982:118).

Figuur 1 Die bestuurstrategie van 'n onderneming: 'n bemarkingsbenadering 
Die 11 motorvoertuigvervaardigers wat aan die navorsing deelgeneem het, het in 1983, 96,02\% (NAAMSA, 1983:1) van die nuwe motorvoertuigmark beheer. Die vier vervaardigers van trekkers het in 1983 ongeveer 85\% (ANON, 1984:23) van die nuwe trekkermark in Suid-Afrika besit en die vyf vervaardigers van landboumasjinerie en -implemente ongeveer $80 \%$ van die mark vir landboumasjinerie en -implemente.

Die ondervragingsmetode is as navorsingsmetode gebruik. Afsprake vir ' $n$ persoonlike besoek is vooraf met die respondente gereël. Gedurende die besoeke is gestruktureerde onderhoude met die senior bemarkingsbestuur van die respondente gevoer. 'n Vooraf-opgestelde vraelys is tydens die onderhoude voltooi. Van die onderhoude het tussen drie en vier ure in beslag geneem. Al die versamelde inligting is met behulp van die BMDP4F-,BMDP3D-en BMDP1D-rekenaarprogramme (Dixon, 1983:1) verwerk.

\section{Bevindinge}

Enkele van die belangrikste bevindinge van die navorsing word bespreek. In die eerste plek word 'n uiteensetting van die bevindinge gegee en vervolgens 'n bespreking oor die implikasies daarvan op die algemene bestuurspraktyk. Die bespreking word aan die hand van die teoretiese model (Figuur 1) gevoer. Tagtig persent van die respondente het aangedui dat hulle wel strategiese bemarkingsbestuur toepas en 'n formele model vir strategieformulering gebruik. Tien persent (een onderneming) pas strategiese bemarkingsbestuur toe, maar op 'n informele wyse, terwyl $10 \%$ (een onderneming) glad nie strategiese bemarkingsbestuur toepas nie.

\section{Bemarkingsinligtingstelsel}

Bemarkingsinligting is vir die formulering van 'n bestuurstrategie nodig. Bemarkingsinligting oor die eksterne omgewing en die interne bemarkingskundighede van die onderneming behoort deur middel van 'n bestuursinligtingstelsel op 'n gesistematiseerde en geordende wyse aan bestuur beskikbaar gestel te word. Al die respondente het aangetoon dat hulle oor ' $n$ bemarkingsinligtingstelsel beskik. In Tabel 1 word 'n uiteensetting gegee van die tegnieke wat deur die respondente vir die versameling van bemarkingsinligting aangewend word. Die resultate van Tabel 1 toon dat die respondente hoofsaaklik kwalitatiewe en kwantitatiewe tegnieke toepas. Die oorsaaklike tegnieke word nie toegepas nie. Die belangrikste rede hiervoor is die gebrek aan deskundige personeel wat die tegnieke kan hanteer. Hierdie gebrek kan slegs oorkom word indien die formele opleiding van bemarkingsbestuurders meer gerig word tot praktiese implementering van die teorie van bemarkingsbestuur as die teorie per se.

In Tabel 2 word die instansies wat vir die insameling van bemarkingsinligting verantwoordelik is, aangedui. Slegs $45 \%$ van die respondente beskik oor 'n eie navorsingsafdeling. In die lig van 'n gebrek aan navorsingsfasiliteite sal dit verwag word dat meer van die navorsingsdienste van byvoorbeeld Universiteite en ander Staatsgesubsidieerde instellings gebruik gemaak sal word. Dit is veral op die terrein van navorsing waar samewerking tussen die Privaatsektor en Staatsgesubsidieerde instellings (byvoorbeeld Universiteite en Technikons) kan lei tot 'n doelmatige aanwending van navorsers en navorsingsfasiliteite. Op dié wyse kan die onderneming gebruik maak van die dienste van deskundiges en inligting verkry wat op 'n wetenskaplike wyse nagevors is.

Die bemarkingstrategie as deel van die beplanningstrategie

Die beplanningstrategie kan beskou word as 'n dinkstrategie.
Tabel 1 Tegnieke vir die insameling en interpretasie van bestuursinligting

\begin{tabular}{|c|c|c|c|c|c|c|c|c|c|}
\hline \multirow[b]{5}{*}{ Tegniek } & \multicolumn{9}{|c|}{$\begin{array}{c}\text { Mate waartoe respondente instaat is om } \\
\text { die tegnieke te gebruik }\end{array}$} \\
\hline & \multicolumn{9}{|c|}{ Alle respondente } \\
\hline & & \multicolumn{8}{|c|}{ Skaal* } \\
\hline & & & 1 & & 2 & & 3 & & 4 \\
\hline & B & A & $\% / \mathrm{B}$ & $\mathbf{A}$ & $\% / B$ & $\mathbf{A}$ & $\% / \mathrm{B}$ & $\mathbf{A}$ & $\% / \mathrm{B}$ \\
\hline Delphi-metode & 20 & 15 & 75,0 & 1 & 5,0 & - & - & 4 & 20,0 \\
\hline $\begin{array}{l}\text { Verbruikersvoorne- } \\
\text { mens (Bemarkingsna- } \\
\text { vorsingsmetode) }\end{array}$ & 20 & 14 & 70,0 & 3 & 15,0 & - & - & 3 & 15,0 \\
\hline $\begin{array}{l}\text { Ekonometriese } \\
\text { modelle }\end{array}$ & 20 & 7 & 35,0 & 5 & 25,0 & 1 & 5,0 & 7 & 35,0 \\
\hline Beswaarde gemiddelde & 20 & 15 & 75,0 & 1 & 5,0 & - & - & 4 & 20,0 \\
\hline $\begin{array}{l}\text { Ekstrapolering van } \\
\text { tydreekse }\end{array}$ & 20 & 16 & 80,0 & 1 & 5,0 & - & - & 3 & 15,0 \\
\hline Leidende reekse & 20 & 17 & 35,0 & 1 & 5,0 & - & - & 2 & 10,0 \\
\hline $\begin{array}{l}\text { Korrelasie en regressie- } \\
\text { analise }\end{array}$ & 20 & 17 & 85,0 & 1 & 5,0 & - & - & 2 & 10,0 \\
\hline Toetsbemarking & 20 & 10 & 50,0 & 2 & 10,0 & - & - & 8 & 40,0 \\
\hline $\begin{array}{l}\text { Inset/Uitset-analise } \\
\text { Analise van produk- }\end{array}$ & 20 & 7 & 35,0 & 6 & 30,0 & 1 & 5,0 & 6 & 30,0 \\
\hline lewensiklusse & 20 & 18 & 90,0 & 1 & 5,0 & - & - & 1 & 5,0 \\
\hline
\end{tabular}

B - Totale aantal respondente per respondentgroep;

A - Respons;

* - Skaal: 1. Pas die tegniek ten volle toe

2. Bewus van die tegniek

3. Ken die tegniek glad nie

4. Het kennis van die tegniek maar gebruik dit nie

Tabel 2 Instansie verantwoordelik vir die insameling van bemarkingsinligting

\begin{tabular}{lrrr}
\hline & \multicolumn{3}{c}{ Alle respondente } \\
\cline { 2 - 4 } Instansie & B & A & $\%$ van B \\
\hline Bemarkingsafdeling & 20 & 18 & 90,0 \\
Navorsingsafdeling & 20 & 9 & 45,0 \\
Private instansies & 20 & 14 & 70,0 \\
Staatsgesubsidieerde instellings, bv. universiteite & 20 & 14 & 70,0 \\
\hline
\end{tabular}

B - Totale aantal respondente; A - Respons

Die bestuur dink en besin tydens die beplanningstrategie oor die onderneming en bemarking.

\section{Die ondernemingsmissie (Corporate mission)}

Die eerste stap in die strategiese bemarkingsbestuurproses is om 'n ontleding van die bestaande ondernemingsmissie te maak, of om indien die onderneming oor geen geskrewe ondernemingsmissie beskik nie, 'n ondernemingsmissie te formuleer (King \& Cleland, 1978:28). Die ondernemingsmissie dui die aard van die sake-aktiwiteite van die onderneming aan. Indien 'n onderneming die bemarkingskonsep as besturursfilosofie aanvaar, moet dit deur die ondernemingsmissie gereflekteer word. Die ondernemingsmissie moet in terme van die wesenskenmerke van die bemarkingskonsep geformuleer word. Die formulering van die ondernemingsmissie is 'n deurslaggewende stap indien 'n onderneming strategiese bemarkingsbestuur toepas. Die ondernemingsmissie bepaal die wese en omskryf die totale ondernemingstelsel. In die ondernemingsmissie moet 'n duidelike omskrywing van die sektor, prodıksietak en bedryfstak waarin die onderneming tans 
sptree, en in die toekoms gaan optree, gegee word (Marx \& 30lt, 1983:33). Tydens die formulering van die ondernemingsnissie is ' $n$ toekomsgeöriënteerde ingesteldheid belangrik. Jndernemings wat outomaties groei as gevolg van hulle nterne vermoëns en hulpbronne word vandag selde aangetref. Groeigeleenthede ontstaan in die eksterne omgewing. Deur die ondernemingsmissie slegs in terme van die interne vermoëns van die onderneming te omskryf word die toekomshorisonne van die onderneming beperk (Levitt, 1980:6).

In Tabel 3 word aangedui dat $80 \%$ van die respondente Dor 'n geskrewe ondernemingsmissie beskik. In $20 \%$ van die gevalle ontbreek ' $n$ baie belangrike en rigtinggewende komponent van die bestuurstrategie. In Tabel 4 word die aspekte wat deur die ondernemingsmissies van die respondente weergegee word aangetoon. 'n Ontleding van die gegewens in Tabel 4 dui daarop dat die markdimensie deur die respondente verwaarloos word. Die gebrek aan 'n duidelike omskrywing van die markdimensie hou vir die ondernemings ' $n$ bedreiging in. Die eksterne orngewing, waarin die geleenthede vir bedreigings voorkom word geignoreer. As gevolg hiervan kan potensiële groeigeleenthede oor die hoof gesien word en word die toekomshorisonne van die ondernemings beperk.

\section{Tabol 3 Ondernemingsmissie}

\begin{tabular}{lccc}
\hline $\begin{array}{l}\text { Beskik oor 'n onder- } \\
\text { nemingsmissie }\end{array}$ & A & B & $\%$ A \\
\hline Ja & 20 & 16 & 80 \\
Nee & & 4 & 20 \\
\hline
\end{tabular}

A - Totale aantal respondente; B - respons

Tabel 4 Aspekte wat deur die ondernemingsmissies weergegee word.

\begin{tabular}{ccrc}
\hline Aspek & A & B & \% van A \\
\hline Sektor & 20 & 17 & 85,0 \\
Produksietak & 20 & 10 & 50,0 \\
Bedryfstak & 20 & 5 & 25,0 \\
Produk & 20 & 17 & 85,0 \\
Mark & 20 & 11 & 55,0 \\
Toekomsgerigtheid & 20 & 12 & 60,0 \\
\hline
\end{tabular}

A - Totale aantal respondente; B - Respons

\section{Ondernemingsdoelwitte}

Die ondernemingsdoelwitte word uit die ondernemingsmissie afgelei. Die ondernemingsdoelwitte is riglyne wat aandui wat gedoen moet word om die ondernemingsmissie te verwesenlik. In Tabel 5 word die belangrikheid van die verskillende ondernemingsdoelwitte vir respondente aangedui. Die resultate in Tabel 5 dui daarop dat die respondente 'n rentabiliteitsgeöriënteerde benadering met betrekking tot doelwitformulering volg. Ondernemingsdoelwitte wat gekoppel kan word aan die sosiaalekonomiese benadering word laag op die doelwithiërargie aangetref. Die verhoging van die welvaart van die gemeenskap word laag op die doelwithiërargie aangetref. Dit beteken egter nie dat die ondernemings nie hulle sosiale verantwoordelikheid nakom nie. Die voortbestaan van die onderneming kan bedreig word indien die onderneming winsmaksimering as die enigste ondernemingsdoelwit beskou, aangesien belangrike aspekte soos navorsing en ontwikkeling, eksterne betrekkinge en die sosiale verantwoordelikheid van die onderneming verwaarloos kan word. In 'n ontwikkelende ekonomie, soos in
Tabel 5 Die belangrikheid van verskillende ondeme mingdoelwitte

\begin{tabular}{|c|c|c|c|c|}
\hline \multirow[b]{2}{*}{ Doelwit } & \multicolumn{4}{|c|}{ Alle respondente } \\
\hline & A & B & $\begin{array}{l}\text { Rang- } \\
\text { orde* }\end{array}$ & C \\
\hline Hoogs moontlike winsgewendheid & 2,200 & 0,60 & 1 & $\overline{2,00}$ \\
\hline $\begin{array}{l}\text { Markwaarde van gewone aandele } \\
\text { so hoog as moontlik te maak }\end{array}$ & 4,700 & 0,56 & 4 & 5,00 \\
\hline Verkoopsgroei in die onderneming & 3,421 & 0,48 & 3 & 3,00 \\
\hline $\begin{array}{l}\text { Bevrediging van verbruikers se } \\
\text { behoeftes }\end{array}$ & 2,750 & 0,68 & 2 & 2,00 \\
\hline $\begin{array}{l}\text { Verhoging van die welvaart van die } \\
\text { gemeenskap }\end{array}$ & 7,050 & 0,39 & 7 & 7,00 \\
\hline $\begin{array}{l}\text { Om altyd eerste op die mark te } \\
\text { wees met 'n nuwe tegnologiese } \\
\text { uitvindsel }\end{array}$ & 7,900 & 0,32 & 9 & 9,00 \\
\hline $\begin{array}{l}\text { Om die alleenverkoper in die mark } \\
\text { te wees }\end{array}$ & 8,850 & 0,16 & 10 & 9,00 \\
\hline $\begin{array}{l}\text { Om risiko van moontlike verkeerde } \\
\text { besluite te vermy }\end{array}$ & 7,150 & 0,17 & 8 & 8,00 \\
\hline Opleiding van werknemers & 5,750 & 0,31 & 6 & 6,50 \\
\hline $\begin{array}{l}\text { Opleiding en ontwikkeling van } \\
\text { bestuurders }\end{array}$ & 5,500 & 0,30 & 5 & 6,00 \\
\hline $\begin{array}{l}\text { * - Gebaseer op gemiddelde wa } \\
10=\text { onbelangrike doelwit) } \\
\text { A - Beswaarde gemiddelde waa } \\
10=\text { onbelangrike doelwit) } \\
\text { B - Koëffisiënt van variansie } \\
\text { C - Mediaan }\end{array}$ & $\begin{array}{l}\text { aarde } \\
\text { larde }\end{array}$ & $\begin{array}{l}=\mathrm{be} \\
=\mathrm{bel}\end{array}$ & $\begin{array}{l}\text { grike } \\
\text { rike }\end{array}$ & $\begin{array}{l}\text { loelwit, } \\
\text { loelwit, }\end{array}$ \\
\hline
\end{tabular}

die geval van die Republiek van Suid-Afrika, is dit belangrik dat ondernemings ' $n$ belegging in die ontwikkeling van die verbruiker moet maak. Hiermee kan 'n hoër lewenstandaard vir die toekoms bevorder word wat op die langtermyn nuwe geleenthede en uitdagings vir die vrye mark kan bied.

Die beoordeling en die vooruitskatting van die eksterne omgewing en die interne vermoëns van die onderneming Die moderne onderneming funksioneer as 'n oop stelsel binne die raamwerk van die eksterne omgewing. Veranderinge wat in die eksterne omgewing plaasvind het ' $n$ invloed op die onderneming. Veranderinge vind ook in die interne vermoëns van die onderneming plaas wat weer ' $n$ invloed op die omgewing het. Die bemarkingsbestuur moet hierdie veranderinge identifseer en ontleed om te bepaal in watter mate die verandering die onderneming en die bestuur in die strewe na doelwitbereiking beïnvloed. Inligting met betrekking tot enige veranderinge wat in die eksterne omgewing en die interne ondernemingstoestand plaasgevind het (of wat verwag word gaan plaasvind), word deur die bedryfsekonomiese ondersoek verkry.

In Tabel 6 word die invloed wat die verskillende eksterne faktore op doelwitbereiking het, aangetoon. Veranderings in die ekonomiese klimaat, vraag na produkitems en mededinging het ' $n$ baie sterk invloed op doelwitbereiking. Die vier vervaardigers van trekkers en die vyf vervaardigers van landboumasjinerie en implemente het aangedui dat verandering in die fisieke omgewing ' $n$ baie sterk invloed op doelwitbereiking het. Dit is veral interessant om daarop te let dat die regeringsbeleid en die politieke klimaat nie as faktore beskou word wat 'n baic sterk invloed op doelwitbereiking het nie (die opname is vanaf Augustus 1984 tot Oktober $1984 \mathrm{ge}$ maak). Die posisie het met die verloop van 1985 sodanig verander dat sakeleiers sterk uitsprake met betrekking tot regeringsbeleid en politieke aangeleenthede maak. Die sosiale leefwyse van die verbruiker en die verbruikerswese word nie as faktore wat doelwitbereiking beïnvloed beskou nie. Hierdie feit kan daarov dui dat die resnondente nie die bemarkings- 
Tabel 6 Die invloed van eksterne faktore op doelwitbereiking

\begin{tabular}{|c|c|c|c|c|c|c|c|c|}
\hline \multirow[b]{3}{*}{ Eksterne faktor } & \multicolumn{8}{|c|}{ Alle respondente } \\
\hline & \multirow[b]{2}{*}{$A^{*}$} & \multirow{2}{*}{$\frac{A}{g \bar{x}}$} & \multirow[b]{2}{*}{ B } & \multicolumn{2}{|c|}{$\leq g \bar{x}$} & \multicolumn{2}{|c|}{$\geq g \bar{x}$} & \multirow[b]{2}{*}{$\mathbf{E}$} \\
\hline & & & & $\mathrm{C}$ & D & $\mathrm{C}$ & D & \\
\hline Verandering in ekonomiese klimaat & 20 & 1,250 & 0,72 & 18 & 80,0 & 2 & 20,0 & $1, \infty$ \\
\hline Verandering in regeringsbeleid & 20 & 2,850 & 0,30 & 5 & 25,0 & 15 & 75,0 & 3,00 \\
\hline Verandering in vraag na produkitems & 20 & 1,050 & 0,21 & 19 & 95,0 & 1 & 5,0 & 1,00 \\
\hline Verandering in mededinging & 20 & 2,050 & 0,48 & 14 & 70,0 & 6 & 30,0 & $2, \infty 0$ \\
\hline Verandering in tegnologie & 20 & 3,250 & 0,32 & 10 & 50,0 & 10 & 50,0 & 3,50 \\
\hline $\begin{array}{l}\text { Verandering in sosiale leefwyse van die } \\
\text { verbruiker }\end{array}$ & 20 & 3,900 & 0,27 & 8 & 40,0 & 12 & 60,0 & 4,00 \\
\hline Verandering in politieke klimaat & 20 & 3,850 & 0,57 & 6 & 30,0 & 14 & 70,0 & 4,50 \\
\hline Die verbruikerswese & 20 & 4,053 & 0,30 & 10 & 50,0 & 10 & 50,0 & 4,00 \\
\hline $\begin{array}{l}\text { Verandering in die fisieke omgewing } \\
\text { byvoorbeeld, reënval }\end{array}$ & 9 & 1,000 & - & 9 & 100,0 & - & - & 1,00 \\
\hline
\end{tabular}

$\mathrm{A}^{*}$ - Totale aantal respondente; $\mathrm{A}-$ Gemiddelde waarde ( $1=$ baie sterk invloed op doelwitbereiking, 5 = geen invloed op doelwitbereiking); B - Koëffisiënt van variansie; C - Respons; D - Persentasie van aantal respondente per respondentgroep; $g \bar{x}-$ Beswaarde gemiddelde waarde $(1=$ baie sterk invloed op doelwitbereiking, 5 = geen invloed op doelwitbereiking); E - Mediaan

Tabel 7 Gereeldheid waarmee veranderings in die eksterne omgewing gemonitor word

\begin{tabular}{|c|c|c|c|c|c|c|c|c|c|c|c|}
\hline \multirow[b]{3}{*}{ Eksterne faktor } & \multicolumn{11}{|c|}{ Alle respondente } \\
\hline & \multirow[b]{2}{*}{ B } & \multicolumn{2}{|c|}{$1 \mathrm{~J} r$} & \multicolumn{2}{|c|}{6 mde } & \multicolumn{2}{|c|}{3 mde } & \multicolumn{2}{|c|}{$1 \mathrm{md}$} & \multicolumn{2}{|c|}{ Glad nie } \\
\hline & & A & $\frac{\%}{B}$ & $\mathbf{A}$ & $\frac{\%}{\mathrm{~B}}$ & A & $\frac{\%}{B}$ & $\mathbf{A}$ & $\frac{\%}{B}$ & $\mathbf{A}$ & $\frac{\%}{\mathrm{~B}}$ \\
\hline Veranderings in ekonomiese klimaat & 20 & 1 & 5,0 & - & - & 4 & 20,0 & 14 & 70,0 & 1 & 5,0 \\
\hline Veranderings in regeringsbeleid & 20 & 1 & 5,0 & 1 & 5,0 & 8 & 40,0 & 9 & 45,0 & 1 & 5,0 \\
\hline Veranderings in vraag na produk & 20 & 1 & 5,0 & - & - & 1 & 5,0 & 18 & 90,0 & - & - \\
\hline Veranderings in mededinging & 20 & 1 & 5,0 & - & - & - & - & 19 & 95,0 & - & - \\
\hline Verandering in tegnologie & 20 & 7 & 35,0 & 4 & 20,0 & 4 & 20,0 & 3 & 15,0 & 2 & 10,0 \\
\hline $\begin{array}{l}\text { Verandering in sosiale leefwyse van die } \\
\text { verbruiker }\end{array}$ & 20 & 14 & 70,0 & 4 & 20,0 & 1 & 5,0 & - & - & 1 & 5,0 \\
\hline Verandering in politieke klimaat & 20 & 7 & 35,0 & 4 & 20,0 & 1 & 5,0 & 6 & 30,0 & 2 & 10,0 \\
\hline Verandering in verbruikerswese & 20 & 9 & 43,0 & 3 & 15,0 & 2 & 10,0 & 2 & 10,0 & 4 & 20,0 \\
\hline $\begin{array}{l}\text { Verandering in fisieke omgewing byvoorbeeld } \\
\text { reënval }\end{array}$ & 20 & - & - & - & - & - & - & 9 & 45,0 & 11 & 55,0 \\
\hline
\end{tabular}

A - Respons; B - Totale aantal respondente

geöriënteerde bestuursbenadering in sy volle reg implementeer en toepas nie.

In Tabel 7 word die gereeldheid waarmee veranderings in die eksterne omgewing gemonitor word, aangedui. Uit Tabelle 6 en 7 blyk 'n duidelike verband tussen die belangrikheid van die invloed wat die eksterne faktore op doelwitbereiking het, en die gereeldheid waarmee veranderings in die eksterne faktore gemonitor word. Die gereeldheidsfrekwensie van die eksterne faktore wat 'n sterk invloed op doelwitbereiking het, is minder as dié van faktore wat nie 'n sterk invloed op doelwitbereiking het nie. 'n Dinamiese veranderende eksterne omgewing vereis dat die bemarkingsbestuur die nie-bestuurbare eksterne faktore op 'n kontinue basis moet monitor en evalueer. Die dinamiese aard van die eksterne omgewing bepaal die gereeldheidsfrekwensie waarvolgens evaluering moet plaasvind. Die ontleding van die eksterne omgewing het ten doel om die geleenthede en bedreigings wat as gevolg van verandering in die eksterne omgewing ontstaan, te identifiseer. Die onderneming se sterk- en swakpunte moet met die geleenthede en bedreigings in die eksterne omgewing in verband gebring word (Ansoff. 1984:38).
Tabel 8 Gereeldheid waarmee sterken swakpunte bepaal word

\begin{tabular}{lccc}
\hline Frekwensie & A & B & $\%$ van A \\
\hline Jaarliks & 20 & 12 & 60,0 \\
Halfjaarliks & 20 & - & - \\
Kwartaalliks & 20 & 3 & 15,0 \\
Maandeliks & 20 & 3 & 15,0 \\
Weekliks & 20 & 1 & 5,0 \\
Glad nie & 20 & 1 & 5,0 \\
\hline
\end{tabular}

A - Totale respondente; B - Respons

In Tabel 8 word die gereeldheid waarmee die sterk- en swakpunte van die respondente se ondernemings bepaal word, aangetoon. In $60 \%$ van dié ondernemings word die sterk- en swakpunte jaarliks bepaal. Die bepaling van die sterk- en swakpunte van die interne vermoëns van die onderneming op 'n jaarlikse basis verskaf aan strategiese bemarkingsbestuur 'n statiese karakter. Strategiese bemarkingsbestuur is 'n dinamiese proses wat vereis dat die sterk- en swakpunt op 'n 
kontinue grondslag in terme van die geleenthede en bedreigings in die eksterne omgewing bepaal moet word. Deur die sterken swakpunte van die onderneming op 'n gereelde korttermyn, in terme van die eise van die mark te bepaal, verkry strategiese bemarkingsbestuur 'n dinamiese karakter. Op dié wyse kan die toepassing van strategiese bemarkingsbestuur 'n bydrae tot die aanpassing en afstemming van die onderneming tot die eksterne omgewing lewer. Indien die onderneming nie vroegtydig bepaal wat die toekomstige sterk- en swakpunte is nie, kan dit gebeur dat veranderings nie betyds gemaak kan word om by die geleenthede en bedreigings in die eksterne omgewing aan te pas nie.

In Tabel 9 word die sterk- en swakpunte, soos deur die respondente aangedui, uiteengesit. Volgens die mediaanwaardes van Tabel 9 het die respondente nie duidelikheid met betrekking tot die sterk- en swakpunte van hulle ondernemings nie. Tydens die onderhoude het van die respondente 'n gebrek aan bemarkingskundigheid, doeltreffende bestuurders en werkerskorps as swakpunte getoon. Die arbeidsprobleme wat die vervaardigers van motorvoertuie in die Republiek van Suid-Afrika het, is nie 'n onbekende faktor nie. Die doeltreffendheid van die bestuur is nie 'n probleem wat oor die korttermyn opgelos kan word nie. As gevolg van die tekort aan bestuur word die bestuur oorlaai met daaglikse operasionele werk wat veroorsaak dat hulle bestuurstaak verwaarloos word. Die opleiding en ontwikkeling van die bemarkingsbestuur in die Republiek van Suid-Afrika is van wesenlike belang.

Tabol 9 Sterk. en swakpunte

\begin{tabular}{lllllll}
\hline & & & & \multicolumn{2}{c}{$\geq g \bar{x}$} \\
\cline { 5 - 7 } \cline { 5 - 6 } Sterk- en swakpunte & A & Mediaan $^{\mathrm{a}}$ & $g \bar{x}$ & B & C \\
\hline Beskikbaarheid en aard van & & & & & \\
grondstof & 20 & 2,00 & 2,200 & 8 & 40,0 \\
Bemarkingskundigheid & 20 & 2,00 & 2,600 & 8 & 40,0 \\
Produksievaardigheid & 20 & 2,00 & 2,300 & 8 & 40,0 \\
Tegnologiese kennis & 20 & 2,00 & 1,500 & 10 & 50,0 \\
Beskikbaarheid van fondse & 20 & 2,00 & 2,350 & 6 & 30,0 \\
Doeltreffende bestuurders & 20 & 2,00 & 2,263 & 14 & 70,0 \\
Doeltreffende werkerskorps & 20 & 2,00 & 2,400 & 8 & 40,0 \\
Beeld van die onderneming & 20 & 2,00 & 2,150 & 7 & 45,0 \\
Produkreputasie & 20 & 2,00 & 2,000 & 6 & 30,0 \\
\hline
\end{tabular}

${ }^{\mathrm{a}} 1$ = Sterkpunt, 5 = swakpunt; $g \bar{x}-$ Rekenkundige gemiddelde; A Totale aantal respondente; $\mathrm{B}-$ Respons; $\mathrm{C}-\mathrm{B}$ as presentasie van $\mathrm{A}$

\section{Die bepaling en beoordeling van geleenthede, bedreigings en doelwitgapings}

Die geleenthede en bedreigings in die eksterne omgewing en die sterk- en swakpunte van die interne vermoëns van die onderneming gee aanleiding tot die ontstaan van doelwitgapings (Cravens, 1982:42). Vanuit 'n bemarkingsbenadering moet ' $n$ bemarkingstrategie geformuleer word om die doelwitgapings te vul. Die bemarkingstrategie word saamgestel uit mark- en produkontwikkelingsbesluite. Die bemarkingstrategie is ' $\mathrm{n}$ verklaring van hoe die onderneming die beskikbare hulpbronne gaan aanwend om die mark te ontwikkel en/of produkte te ontwikkel om sodoende doelwitgapings te vul.

In Tabel 10 word aangetoon dat $80 \%$ van die respondente oor 'n geskrewe bemarkingstrategie beskik. Een respondent het aangedui dat die onderneming wel oor ' $n$ bemarkingstrategie beskik maar dat dit nie op skrif gestel is nie, terwyl een
Tabel 10 Geskrewe bemarkingstrategie

\begin{tabular}{lrrr}
\hline \multirow{2}{*}{$\begin{array}{l}\text { Beskik die onderneming oor 'n geskrewe } \\
\text { bemarkingstrategie? }\end{array}$} & \multicolumn{3}{c}{ Respondente } \\
\cline { 2 - 4 } & A & B & $\%$ van A \\
\hline $\mathrm{Ja}$ & 20 & 18 & 90,0 \\
$\mathrm{Nee}$ & 20 & 2 & 10,0 \\
\hline
\end{tabular}

A - totale aantal respondente; B - Respons

Tabel 11 Tegnieke vir die evaluering van alternatiewe strategieë

\begin{tabular}{lrrc}
\hline & \multicolumn{3}{c}{ Alle respondente } \\
\cline { 2 - 4 } Tegniek & A & \multicolumn{1}{c}{ B } & $\%$ van A \\
\hline 'WOTS-UP' analises & 20 & 15 & 80,0 \\
Gapingsanalise & 20 & 15 & 75,0 \\
Strategiese profiel & 20 & 8 & 40,0 \\
Produk-/mark matrikse & 20 & 9 & 45,0 \\
Produklewensiklusse & 20 & 16 & 80,0 \\
Produkportefeulje & 20 & 5 & 25,0 \\
Simulasie & 20 & 9 & 45,0 \\
Intuïsie & 20 & 2 & 10,0 \\
Geluk & 20 & 6 & 30,0 \\
Geen benadering & 20 & 1 & 5,0 \\
\hline
\end{tabular}

A - Totale aantal respondente in respodentgroep; $\mathrm{B}$ Respons

onderneming glad nie oor ' $n$ bemarkingstrategie beskik nie. As gevolg van die verskeidenheid nie-bestuurbare en bestuurbare faktore wat ' $n$ invloed op strategieformulering het, is dit noodsaaklik om die bemarkingstrategie in ' $n$ formele geskrewe dokument saam te vat. Die formulering van die bemarkingstrategie kan nie in 'n dinamiese omgewing op ' $n$ lukraak wyse plaasvind nie. Alle tersaaklike faktore en invioede moet in berekening gebring word sodat brontoekenning op die mes doeltreffende en doelmatige wyse kan geskied.

In Tabel 11 word 'n uiteensetting gegee van die metodes of tegnieke wat deur die respondente gebruik word om alternatiewe strategieë en wyses van hulpbrontoekenning mee te identifiseer en te evalueer. Die belangrikste tegnieke of metodes wat deur die respondente gebruik word tydens die identifisering van alternatiewe strategieë, is die 'WOTS-UP' analise, produklewensiklusse en gapingsanalise. Die meer gesotistikeerde tegnieke naamlik produk-/markmatrikse, strategiese profiele en die produkportefeuljebenadering word slegs deur 'n klein persentasie respondente gebruik. Die belangrikste rede hiervoor is 'n gebrek aan opgeleide personeel wat hierdie tegnieke kan hanteer. Dertig persent van die respondente het aangedui dat geluk ' $n$ rol in die bepaling van die bemarkingstrategie speel. Navorsing behoort oor die implementering en gebruik van die portefeuljebenaderings onder Suid-Afrikaanse bemarkingstoestande gedoen te word. Die bemarkingsbestuur het ' $\mathrm{n}$ verantwoordelikheid om toe te sien dat die hulpbronne tot sy beskikking doelmatig aangewend word. Die doelmatige toekenning van hulpbronne is slegs moontlik indien die tegnieke toegepas kan word waarmee produkte en markte, wat die hoogs moontlike opbrengs op insette kan lewer, geidentifiseer kan word.

Die bemarkingstrategie as deel van die operasionele strategie.

Die operasionele strategie is die instrument waarmee die beplanningstrategie tot optrede omgeskakel word. Die operasionele strategie kan dus na verwys word as die doenstrategie 
(sien Figuur 1). In die operasionele strategie word omvattend omskryf watter bemarkingsaktiwiteite uitgevoer moet word, die persone wat dit moet uitvoer, die tydstippe waarop dit uitgevoer moet word en die hulpbronne wat nodig is om die doelmatige uitvoering van dié aktiwiteite moontlik te maak. Die verskillende komponente van die bemarkingstrategie moet gekoördineer en geïntegreer word, want as afsonderlike komponente beteken hulle weinig (Lucas, de Coning, Marx \& Oosthuizen, 1979:292). Die bestuur bestee baie tyd aan die formulering van die bemarkingstrategie maar die strategie word nie geimplementeer nie as gevolg van die gebrek aan 'n werkbare dokument waardeur die strategie aan al die partye wat vir die implementering daarvan verantwoordelik is, bekend gestel kan word (Abell \& Hammond, 1979:457). Die instrument waarmee die komponente van die bemarkingstrategie geïntegreer en gekoördineer word is die bemarkingsplan. Die bemarkingsplan is in wese ' $n$ werkbare dokument waardeur die bemarkingstrategie tot uitvoering gebring word. In Tabel 10 is reeds aangedui dat $80 \%$ van die respondente wel oor 'n geskrewe bemarkingstrategie (dus 'n bemarkingsplan) beskik.

In Tabel 12 word die komponente waaruit die respondente se bemarkingsplanne saamgestel word uiteengesit. Uit Tabel 12 blyk dit dat die bemarkingsplanne onvolledig is en nie al die komponente wat in 'n bemarkingsplan opgeneem moet word bevat nie. Die onvolledigheid van die bemarkingsplanne kan daarop dui dat die beplanningstrategie nie werklik omgeskakel word na 'n operasionele strategie nie. Sommige respondente het tydens die onderhoude aangedui dat strategiese bemarkingsbestuur ' $n$ 'papieroefening' is. Hierdie houding is toe te skryf aan die gebrek aan 'n werkbare dokument, naamlik die bemarkingsplan. Die uitstaande probleemgebied wat tydens die navorsing geidentifiseer is, is die omskakeling van die beplanningstrategie na ' $n$ operasionele strategie. Strategiese bemarkingsbestuur word as ' $n$ 'oefening' beskou wat jaarliks afgehandel word. Die denkproses (beplanningstrategie) vind plaas maar die doenproses (operasionele strategie) ontbreek nog.

Tabel 12 Komponente van die bemarkingsplan

\begin{tabular}{lrrc}
\hline & \multicolumn{3}{c}{ Respondente } \\
\cline { 2 - 4 } Komponent & A & B & \% van A \\
\hline Historiese inligting & 20 & 9 & 45,0 \\
Vooruitskattings & 20 & 14 & 70,0 \\
Sterk- en swakpunte & 20 & 14 & 70,0 \\
Geleenthede en bedreigings & 20 & 12 & 60,0 \\
Doelwitte & 20 & 16 & 80,0 \\
Bemarkingsresep & 20 & 16 & 80,0 \\
Bemarkingsprogram & 20 & 16 & 80,0 \\
Bemarkingsbegroting & 20 & 15 & 75,0 \\
\hline
\end{tabular}

A - Totale aantal respondente; B - Respons

\section{Slotopermerking}

Die vernaamste bevinding uit die navorsing is dat die leweransiers van kapitaaltoerusting (wat aan die navorsing deelgeneem het) aan die landbou in die Republiek van Suid-Afrika, met enkele uitsonderings, nie strategiese bemarkingsbestuur toepas nie. Die bevinding word gebasseer op die feit dat die beplanningstrategie nie omgeskakel word tot 'n operasionele strategie nie. Die strategiese bemarkingsbestuurproses eindig dus by die dinkproses en word nie tot aksie, wat op die denkproses gebasseer is, deurgevoer nie.
In die lig van veranderinge wat moontlik in die toekoms gaan plaasvind (byvoorbeeld die afskaffing van prysbeheer en tariefbeskerming) wat die Suid-Afrikaanse ekonomie meer 'oop' en meer mededingend met ander ekonomieë kan maak, is dit belangrik dat die bemarkingsbestuur ' $n$ strategiese benadering tot bemarkingsbestuur moet toepas. Hierdeur kan moontlik verseker word dat die geleenthede en bedreigings in die eksterne omgewing benut of oorkom word en dat hulpbronne optimaal aangewend word. In die lig van bogenoemde kan die belangrikheid van die opleiding van bemarkingsbestuur in strategiese bemarkingsbestuur, nie verwaarloos of onderskat word nie.

\section{Summary}

Despite the important role and influence of the external environment on the functioning of the individual firm, it is not always clear whether sufficient time and attention are devoted to the analysis of the external environment during the formulation of management and marketing strategies. The aim of this research was to determine how the marketing management of some suppliers of capital equipment to the agricultural sector apply strategic marketing principles and practices to enable their firms to adapt to constant external changes.

Apart from the theoretical background, some empirical research was undertaken to determine the composition of the management and marketing strategies. The emphasis was, however, on the formulation and the implementation of the marketing strategy.

An analysis of the different marketing systems applied by the respondents revealed that most of the systems are inadequate for the implementation of strategic marketing management. The respondents tend to analyse only the quantitative external forces. They neglect important non-quantitative forces such as the social lifestyle of the consumer. The marketing plans of $65 \%$ of the respondents were incomplete which may be due to the fact that the planning strategy is not transformed to an operational strategy. The lack of an operational strategy tends to give the strategic marketing management process the characteristic of a 'paper exercise'.

The major finding of this research was that the majority of the suppliers of capital equipment to the agricultural sector do not apply strategic marketing management principles and practices. The finding is based on the fact that the planning strategy is not transformed to an operational strategy. In view of this one cannot but stress the importance of thorough scientific training in strategic marketing management.

\section{Verwysings}

ANON. 1984. Delivering the goods. Bus. S. Afr. $9(4), 36-38$, Apr.

ABELL, D.F. \& HAMMOND, J.L. 1979. Strategic market planning. Englewood Cliffs: Prentice-Hall.

ANSOFF, H.I. 1984. Implanting strategic management. New Jersey: Prentice-Hall.

CHURCHILL, G.A. 1983. Marketing research: methodological foundations. Chicago: The Dryden Press.

CRAVENS, D.W. 1982. Strategic marketing. Illinois: Richard D Irwin.

DIXON, W.J. 1983. BMDP Statistical software. Berkeley: University of California Press.

GODIVALLA, Y.H. 1983. Strategic management, broadening business policy. New York: Praeger Publishers.

HOFER, C.W. \& SCHENDEL, D. 1978. Sirategy formulation: analytical concepts. St. Paul: West Publishing Company.

KING, W.R. \& CLELAND, D.I. 1978. Strategic planning and policy. New York: Van Nostrand Reinhold Company. 
KOTLER, P.K. 1980. Marketing management: analysis, planning and control. Englewood Cliffs: Prentice-Hall.

LEVITT, T. 1980. Marketing Myopia. In: Kotler, P. (red.) Marketing management and strategy. New Jersey: Prentice Hall, p. 3-20.

LUCAS, G.H.G., DE CONING, C., MARX, S. \& OOSTHUIZEN, H. 1979. Die taak van die bemarkingsbestuur. Pretoria: J.L. van Schaik (Edms.) Beperk.
LUCK, D.J. \& FERREL, O.C. 1979. Marketing strategy and plans. Englewood Cliffs: Prentice-Hall.

MARX, S. \& BOLT, J. 1983. Bestuurstrategie en produkbestuite. Kaapstad: Juta en Kie.

NAAMSA. 1983. NAAMSA CAR SALES, Cumulative statistic for the year 1983. Pretoria.

STEINER, G.A. \& MINER, J.B. 1977. Management policy and strategy. New York: McMillan. 